\title{
Persepsi Masyarakat Sekitar Terhadap Aktivitas PT. IKPP Mills Tangerang
}

\section{Perception Of Community In Around PT. IKPP Mills Tangerang}

\author{
Siti Hani Rahmanita ${ }^{1}$, Ninuk Purnaningsih ${ }^{2}$ \\ ${ }^{1}$ Departemen Sains Komunikasi dan Pengembangan Masyarakat FEMA IPB \\ ${ }^{2}$ Dosen Departemen Sains Komunikasi dan Pengembangan Masyarakat FEMA IPB
}

\begin{abstract}
This research is about perception of community in around PT. IKPP Mills Tangerang to that mills activities based on individual and external factors. Beside that, this research studies about mills effort to influence community in around mills perception that includes communication and corporate social responsibility (CSR). In this research, identification of perceptions is from five aspects includes perception toward mills basic material, machine, and instrument; perception toward mills staff situation; perception toward millsproduction process; perception toward mills waste; and perception toward mills impact to the social, economic, and environment. The result of this research is most of the respondents have positive perceptions toward mills activities, except toward mills waste. This research useful for mills sustainability guarantee by increase their positive impact to the community in the operation area.
\end{abstract}

Keywords: perception, mills activities aspects, mills efforts to influence community in around mills perception

\begin{abstract}
Abstrak
Penelitian ini adalah tentang persepsi masyarakat di sekitar PT IKPP Mills terhadap aktivitas PT. IKPP Mills Tangerang untuk kegiatan pabrik berdasarkan faktor individu dan faktor eksternal. Selain itu, penelitian ini mempelajari tentang upaya pabrik untuk mempengaruhi persepsi masyarakat sekitar pabrik yang meliputi komunikasi dan tanggung jawab sosial perusahaan (CSR). Dalam penelitian ini, identifikasi dari persepsi dilihat dari lima aspek termasuk persepsi terhadap pabrik berdasarkan bahan dasar, mesin, dan instrumen; persepsi terhadap situasi staf pabrik; persepsi terhadap proses produksi pabrik; persepsi terhadap limbah pabrik; dan persepsi terhadap pengaruh pabrik pada sosial, ekonomi, dan lingkungan. Hasil dari penelitian ini adalah sebagian besar responden memiliki persepsi positif terhadap kegiatan pabrik, kecuali terhadap limbah pabrik. Penelitian ini berguna untuk jaminan pabrik keberlanjutan dengan meningkatkan dampak positif pabrik kepada masyarakat di daerah operasi.
\end{abstract}

Kata kunci: persepsi, aspek kegiatan pabrik, upaya pabrik untuk mempengaruhi masyarakat disekitar pabrik

\section{Pendahuluan}

Perusahaan dan masyarakat yang bermukim di sekitarnya merupakan dua komponen yang saling mempengaruhi. Aktivitas produksi yang dilakukan oleh perusahaan memiliki dampak terhadap masyarakat di sekitarnya, baik positif maupun negatif. Begitupun sebaliknya, pandangan atau tindakan masyarakat sekitar perusahaan dapat mempengaruhi keberlanjutan keberadaan sebuah perusahaan di wilayah tertentu.
Interaksi di antara keduanya merupakan suatu hal yang tidak dapat dihindarkan karena mereka berada dalam lingkungan yang sama. Aktivitas perusahaan memiliki dampak terhadap masyarakat sekitarnya. Dampak tersebut dapat berupa dampak positif seperti antara lain penciptaan lapangan pekerjaan dan peningkatan ekonomi, maupun dampak negatif seperti antara lain penurunan kualitas lingkungan dan kesehatan masyarakat. Namun, bagian 
mana yang lebih menonjol dari kedua dampak tersebut tergantung dari sudut mana masyarakat memandangnya. Apabila dampak positif lebih menonjol dibandingkan dampak negatif di mata masyarakat sekitar, maka hal tersebut tentu akan menguntungkan bagi perusahaan. Hal yang tidak diinginkan adalah apabila yang terjadi merupakan hal yang sebaliknya. Akibatnya, kegiatan perusahaan dan

proses produksinya dapat terhambat sebagaimana yang dialami oleh PT. Freeport Indonesia pada tahun 20061.

Menurut Ambadar (2008), paradigma perusahaan yang hanya berorientasi memperoleh laba (profit) sebesar-besarnya sudah mulai bergeser dan mulai berupaya memberikan dampak positif keberadaannya bagi kesejahteraann masyarakat sekitar. Lebih lanjut Ambadar (2008) memaparkan bahwa komunitas bisnis di berbagai negara telah semakin menyadari bahwa pembangunan berkelanjutan suatu perusahaan hanya dapat dipertahankan apabila terdapat keseimbangan antara aspek ekonomi, sosial, dan lingkungan hidup yang mendukungnya. Aktivitas kepedulian perusahaan ini salah satunya diwujudkan dalam tanggung jawab sosial perusahaan (corporate social responsibility/CSR).

Beberapa manfaat yang dapat dirasakan oleh perusahaan melalui kegiatan tanggung jawab. Data pemerintah menyebutkan jumlah kemiskinan di Indonesia lebih dari $30 \%$ populasi, sedangkan pengangguran sudah mencapai 40 juta orang penduduk (Ambadar, 2008). Perusahaan sebagai upaya pengembangan masyarakat berdasarkan hasil penelitian

Herlin (2008) adalah untuk mempublikasikan keberadaannya sehingga hubungan yang baik dengan stakeholder (dalam hal ini masyarakat) dapat terwujud dan membina hubungan baik dengan masyarakat sehingga tidak terjadi konflik.Upaya perusahaan untuk memperbaiki persepsi masyarakat sekitar lainnya adalah melalui penerapan komunikasi perusahaan. Menurut Hadi (2001) hubungan perusahaan dengan komunitas merupakan suatu tindakan yang harus dilakukan perusahaan untuk memelihara dan membina hubungan dengan lingkungannya melalui komunikasi yang saling menguntungkan. Oleh karena itu, komunikasi perusahaan diharapkan dapat menjangkau semua lapisan masyarakat. PT. Indah Kiat Pulp and Paper Mills (PT. IKPP) Tangerang merupakan salah satu perusahaan terkemuka di Indonesia yang berdiri di tengah masyarakat. Laporan keberlanjutan lingkungan dan sosial Asia Pulp and Paper (APP) untuk Indonesia tahun 2005-2006 menyebutkan bahwa PT. IKPP Mills Tangerang merupakan pabrik kertas pertama di Indonesia yang mendapatkan sertifikat ISO 14001 pada tahun 1996. PT. IKPP Mills Tangerang telah mendapatkan peringkat "hijau" dalam Program Penilaian Peringkat Kinerja Perusahaan dalam Pengelolaan Lingkungan Hidup (PROPER) pada periode 2006-2007 yang dikembangkan oleh Kementrian Negara Lingkungan Hidup (Menlh 2009).

Adapun kegiatan sosial yang telah dilakukan PT. IKPP Mills Tangerang secara rutin antara lain sunatan massal, program beasiswa, bantuan sarana dan prasarana komunitas sekitar pabrik, dan lainnya. Sejauhmana upaya perusahaan tersebut dapat memperbaiki persepsi masyarakat sekitar terhadap aktivitas perusahaan merupakan hal yang menarik

peneliti untuk melaksanakan penelitian ini. Berdasarkan latar belakang yang telah dipaparkan tersebut, maka rumusan masalah dari penelitian ini adalah: Bagaimana persepsi masyarakat sekitar terhadap aktivitas PT. IKPP Mills Tangerang dan Bagaimana upaya PT. IKPP Mills Tangerang untuk memperbaiki persepsi masyarakat sekitar?

\section{Metodologi Penelitian}

Penelitian ini bertujuan untuk mengukur persepsi masyarakat sekitar terhadap aktivitas perusahaan, sehingga peneliti menggunakan pendekatan kuantitatif dengan menggunakan metode survei, yaitu 
wawancara dengan menggunakan kuesioner, untuk kemudian seluruh jawaban yang diperoleh peneliti dicatat, diolah, dan dianalisis (Prasetyo dan Jannah, 2005). Data lapang dikumpulkan pada akhir bulan Mei 2009 sampai dengan awal bulan Juli 2009. Lokasi penelitian ini adalah PT. Indah Kiat Pulp and Paper (PT. IKPP) Mills Tangerang dan penduduk RT 005/002 Kampung Baru Selatan, Kelurahan Pakulonan, Kecamatan Serpong Utara, Kabupaten Tangerang. Lokasi dipilih karena perusahaan yang berdiri sejak tahun 1976 ini telah memberikan dampak, baik yang positif maupun yang negatif, terhadap masyarakat di sekitarnya yaitu penduduk RT 005/002 Kampung Baru Selatan.

Responden yang dipilih merupakan penduduk yang telah berusia 17 tahun dan/atau 17 tahun ke atas di daerah yang berbatasan dengan PT. Indah Kiat Pulp and Paper (PT. IKPP) Mills Tangerang serta merasakan dampak yang ditimbulkan oleh perusahaan yaitu RT 005/002 Kampung Baru Selatan, Kelurahan Pakulonan, Kecamatan Serpong Utara, Kabupaten Tangerang, Propinsi Banten. Adapun populasi penelitian ini berjumlah 434 orang. Besaran sampel yang digunakan berdasarkan perhitungan dengan menggunakan rumus Slovin dengan nilai kritis (e) sebesar 15 persen adalah 40 orang. Penelitian ini menggunakan data primer dan data sekunder. Data primer didapatkan dari hasil wawancara terstruktur dengan menggunakan kuesioner dan mewawancarai sejumlah informan dengan menggunakan panduan pertanyaan untuk mendukung data hasil survei. Data sekunder didapatkan dari analisis dokumen-dokumen dan pustaka yang berasal antara lain dokumen kelurahan dan dokumen perusahaan.

Data yang diperoleh diolah dengan menggunakan program Statistical Program for Social Sciences (SPSS version 16.0). Data tersebut ditabulasi dan dianalisis secara deskriptif. Data juga dianalisis dengan menggunakan uji korelasi Rank Spearman dan uji Kai Kuadrat (X2).

\section{Hasil Dan Pembahasan}

\section{Faktor Individu Responden Penelitian}

\section{Tingkat Kesejahteraan}

Variabel tingkat kesejahteraan dalam penelitian ini diidentifikasi dari prioritas pengeluaran responden untuk memenuhi kebutuhannya yang mencakup kebutuhan makan, perumahan, pendidikan, kesehatan, rekreasi, barang mewah, ibadah, modal bisnis, pakaian, dan tabungan. Tabel 1 menunjukkan beberapa prioritas kebutuhan yang menempati urutan pertama atau merupakan pengeluaran terbesar responden dalam satu bulan. Kebutuhan tersebut antara lain makan, tabungan, perumahan, pendidikan, dan modal bisnis. Responden dalam penelitian ini sebagian besar memprioritaskan kebutuhan makan sebagai pengeluaran terbesar setiap bulannya.

Tabel 1. Jumlah, Persentase, dan Kategori Responden Berdasarkan Prioritas Kebutuhannya

\begin{tabular}{lccl}
\hline \multicolumn{1}{c}{ Prioritas Kebutuhan } & Jumlah & Persen $(\%)$ & Kategori \\
\hline Makan & 28 & 70 & Belum sejahtera \\
Pendidikan & 5 & 12 & Sejahtera \\
Modal bisnis & 4 & 10 & \\
Tabungan & 2 & 5 & \\
Perumahan & 1 & 3 & \\
\hline
\end{tabular}

Ket $\mathrm{n}=40$ 


\section{Karakteristik Sosial Ekonomi}

Karakteristik sosial ekonomi dalam penelitian ini mencakup umur, jenis kelamin, tingkat pendidikan, jenis pekerjaan, tingkat pendapatan, dan status sosial responden. Berdasarkan Tabel 2 diketahui bahwa seluruh responden berada dalam usia produktif dan didominasi oleh perempuan $(62,5 \%)$. Hal ini dapat disebabkan oleh waktu penelitian yang sebagian besar dilaksanakan ada jam kerja berlangsung dan pada hari kerja. Sebagian besar responden perempuan tersebut ditemui di rumah masing-masing. Responden perempuan tersebut sebagian besar bekerja tidak jauh dari lokasi tempat tinggalnya sehingga lebih mudah ditemui. Ada yang merupakan ibu rumah tangga, pegawai pabrik, guru di SD di lingkungan tersebut dan pedagang yang berjualan di sekitar rumahnya. Sedangkan responden laki-laki memiliki jam kerja yang lebih lama yaitu hingga sore hari ataupun berada di luar kota pada hari kerja dan hanya dapat ditemui pada hari libur (sabtu dan minggu).

Sebagian besar (36\%) responden memiliki tingkat pendidikan yang rendah. Pendidikan terakhir tertinggi masyarakat sekitar yang menjadi responden adalah S1 serta sebagian besar responden berpendidikan SMA (sederajat). Terdapat pula responden yang tidak pernah bersekolah. Tokoh masyarakat setempat juga mengatakan bahwa sebagian besar warganya bersekolah hingga tingkat SMA. Hanya sebagian kecil warganya yang mampu yang dapat melanjutkan sekolah hingga tingkat yang lebih tinggi.

Tabel 2. Jumlah, Persentase, dan Kategori Responden Berdasarkan Karakteristik Sosial Ekonomi

\begin{tabular}{|c|c|c|c|}
\hline $\begin{array}{l}\text { Karakteristik Sosial } \\
\text { Ekonomi Responden }\end{array}$ & Kategori & Jumlah & $\begin{array}{l}\text { Persen } \\
(\%)\end{array}$ \\
\hline \multirow[t]{2}{*}{ Usia } & 1. Produktif (15-64 tahun) & 40 & 100 \\
\hline & 2. Non Produktif ( $>64$ tahun) & 0 & 0 \\
\hline \multirow[t]{2}{*}{ Jenis kelamin } & 1. Laki-laki & 15 & 37,5 \\
\hline & 2. Perempuan & 25 & 62,5 \\
\hline \multirow[t]{2}{*}{ Tingkat pendidikan } & 1. Tinggi & 4 & 10 \\
\hline & 2. Rendah & 36 & 90 \\
\hline \multirow[t]{3}{*}{ Jenis pekerjaan } & 1. Berhubungan langsung dengan perusahaan & 6 & 15 \\
\hline & $\begin{array}{l}\text { 2. Tidak berhubungan langsung dengan } \\
\text { perusahaan }\end{array}$ & 16 & 40 \\
\hline & 3. Tidak bekerja & 18 & 45 \\
\hline \multicolumn{4}{|l|}{ Tingkat Pendapatan } \\
\hline \multirow{2}{*}{$\begin{array}{l}\text { 1. Tingkat pendapatan } \\
\text { individu }\end{array}$} & 1. $\leq \operatorname{Rp} 941.250,00($ rendah $)$ & 23 & 57 \\
\hline & 2. $>\operatorname{Rp} 941.250,00$ (tinggi) & 17 & 43 \\
\hline \multirow[t]{2}{*}{ 2.Tingkat pendapatan } & 1. $\leq \mathrm{Rp} 1.941 .250,00$ (rendah) & 17 & 43 \\
\hline & 2. $>\operatorname{Rp} 1.941 .250,00$ (tinggi) & 23 & 57 \\
\hline \multirow[t]{2}{*}{ Status sosial } & 1. Tokoh masyarakat & 3 & 7 \\
\hline & 2. Bukan tokoh masyarakat & 37 & 93 \\
\hline
\end{tabular}

Ket $n=40$

Jenis pekerjaan responden dalam penelitian ini dibagi menjadi tiga kategori, yaitu berhubungan langsung dengan perusahaan/pabrik, tidak berhubungan langsung dengan perusahaan/pabrik, dan tidak bekerja. Berdasarkan ketiga hal tersebut terdapat 15 persen responden yang memiliki pekerjaan berhubungan langsung dengan pabrik, 40 persen responden yang memiliki pekerjaan tidak berhubungan langsung dengan pabrik, dan 45 persen responden tidak bekerja. Responden yang memiliki pekerjaan berhubungan langsung dengan perusahaan/pabrik sebagian besar 
bekerja di bagian produksi di pabrik. Terdapat pula responden yang bekerja di PT. IKPP Mills Tangerang. Responden yang memiliki pekerjaan tidak berhubungan langsung dengan perusahaan/pabrik terdiri dari aparat pemerintahan (RT), buruh (bangunan dan lainnya), pegawai toko, mekanik, PNS (kelurahan), guru, wirausaha (pedagang, pemilik rumah kontrakan, dan pemulung), dan guru mengaji (ustad). Responden yang tidak bekerja terdiri dari ibu rumah tangga, pelajar SMA, mahasiswa, dan pencari kerja (pengangguran). Responden yang termasuk dalam pencari kerja (pengangguran) tersebut beberapa diantaranya merupakan pelajar yang lulus SMA pada tahun 2009.

Rentang pendapatan individu yang didapatkan di lokasi penelitian adalah $\mathrm{Rp}$ 0,00 - Rp 5.000.000,00. Berdasarkan hasil penelitian, dapat diketahui bahwa sebagian besar responden (57 persen) memiliki pendapatan individu yang rendah. Artinya, sebagian besar responden memiliki pendapatan di bawah rata-rata pendapatan individu. Rentang pendapatan keluarga responden berdasarkan hasil penelitian adalah Rp 400.000,00-Rp 5.000.000,00. Berbeda dengan tingkat pendapatan individu responden yang cenderung rendah, sebagian besar pendapatan responden (57 persen) memiliki tingkat pendapatan yang tinggi. Artinya, sebagian besar keluarga responden memiliki tingkat pendapatan di atas rata-rata pendapatan keluarga.

Status sosial dalam penelitian ini dikategorikan menjadi tokoh masyarakat dan bukan tokoh masyarakat. Tokoh masyarakat merupakan orang yang memiliki pengaruh dan disegani di masyarakat, dimana pendapatnya akan didengarkan dan menjadi panutan masyarakat lainnya. RT 005/02. Berdasarkan hasil wawancara, maka diketahui terdapat 3 orang ( 7 persen) responden yang merupakan tokoh masyarakat dalam penelitian ini. Tiga orang tokoh masyarakat tersebut terdiri dari warga yang menjabat sebagai Ketua RT pada saat ini yaitu Bapak Rsd, pemuka agama/guru mengaji yaitu Bapak Io, dan mantan ketua
RT yaitu Bapak Skm. Ketiga tokoh tersebut, meskipun dianggap masih kurang dominan di mata masyarakat, namun memiliki pengaruh dan merupakan tempat masyarakat untuk meminta pendapat mengenai permasalahan RT. Responden lainnya yang tergolong bukan tokoh masyarakat sebagian besar merupakan pendatang dan kurang terlibat dalam menyelesaikan masalah RT karena cenderung sibuk bekerja. Mereka juga cenderung mempercayakan permasalahan RT kepada tokoh masyarakat setempat.

\section{Upaya Perusahaan Mempengaruhi Persepsi Masyarakat Sekitar}

\section{Penerapan Pola Komunikasi PT. IKPP Mills Tangerang}

PT. IKPP Mills Tangerang berupaya menjalin hubungan baik dengan masyarakat sekitar dengan melakukan komunikasi. Upaya ini dilakukan perusahaan melalui kunjungan dan menyebarkan kuesioner. Menurut beberapa responden, PT. IKPP Mills Tangerang mengirim petugas lapang yang tidak lain adalah karyawan bagian hubungan masyarakat (humas) perusahaan setiap kali PT. IKPP Mills Tangerang membuang limbah ke sungai. Humas tersebut melakukan pengontrolan pembuangan limbah dan menjelaskan kepada masyarakat sekitar yang dekat dengan tempat pembuangan limbah perusahaan mengenai limbah yang dibuang tersebut sekaligus meminta maaf apabila terdapat bau tidak sedap yang mengganggu. Humas tersebut juga sempat tinggal di lingkungan masyarakat sekitar untuk beberapa waktu sehingga masyarakat sekitar cukup mengenalnya. Saat penelitian ini berlangsung, humas tersebut telah pindah dari lingkungan masyarakat sekitar.

Pihak perusahaan mengatakan bahwa pada awalnya sulit untuk mengajak masyarakat sekitar agar mau mengisi kuesioner tersebut. Banyak masyarakat sekitar yang tidak bersedia mengisinya dengan berbagai alasan. Namun setelah 
perusahaan menyiasatinya dengan memberikan imbalan sebesar Rp 5000,00 bagi setiap orang yang mau mengisi kuesioner tersebut, masyarakat sekitar kemudian bersedia untuk mengisinya. Penyebaran kuesioner ini merupakan salah satu upaya PT. IKPP Mills Tangerang untuk menerima umpan-balik atau tanggapan dari masyarakat sekitar terhadap upaya-upaya yang dilakukan perusahaan dalam membina hubungan baik dengan masyarakat sekitar dan aktivitas PT. IKPP Mills Tangerang, sehingga PT. IKPP dapat menampungnya sebagai masukan. Pihak perusahaan mengatakan bahwa perusahaan menyikapi tanggapan masyarakat sekitar tersebut dengan cara rutin melakukan komunikasi, mulai memasang lowongan pekerjaan di kelurahan, dan melakukan kegiatan sosial untuk seluruh masyarakatan bukan untuk pribadi maupun golongan. Namun, sebagian besar responden mengatakan tidak mengetahui bagaimana tindak lanjut dari penyampaian pendapat mereka melalui selebaran tersebut.

Kegiatan komunikasi yang dilakukan oleh PT. IKPP Mills Tangerang terhadap masyarakat sekitar tidak dilakukan secara rutin. Adapun cara yang ditempuh PT. IKPP Mills Tangerang dalam menyampaikan suatu informasi kepada masyarakat adalah dengan menghubungi pihak kelurahan dan tokoh masyarakat setempat. Informasi yang biasanya disampaikan oleh PT. IKPP Mills Tangerang adalah informasi mengenai kegiatan sosial perusahaan.

Berdasarkan beberapa keterangan yang telah diungkapkan mengenai kegiatan komunikasi untuk membina hubungan baik dengan masyarakat sekitar yang dilakukan oleh PT. IKPP Mills Tangerang, maka dapat diketahui bahwa kegiatan komunikasi tersebut tergolong dalam model asimetris dua arah. PT. IKPP Mills Tangerang telah berusaha untuk menangkap umpan-balik dari masyarakat sekitarnya dengan cara menyebarkan kuesioner dan mendekati tokoh masyarakat untuk mengetahui isu-isu yang sedang berkembang.

\section{Pelaksanaan Kegiatan Tanggung Jawab Sosial Perusahaan PT. IKPP Mills Tangerang}

Upaya PT. IKPP Mills Tangerang dalam membina hubungan baik dengan masyarakat sekitar melalui tanggung jawab sosial perusahaan telah tertulis (formal) dalam kebijakan perusahaan. Selain itu, PT. IKPP Mills Tangerang memiliki bagian khusus yang menangani kegiatan tanggung jawab sosial perusahaan. PT. IKPP Mills Tangerang telah melakukan kegiatan tanggung jawab sosial perusahaan dalam jangka waktu tiga tahun terakhir. Tanggung jawab sosial perusahaan tersebut diberikan dalam bentuk uang dan natura (barang/jasa). Tanggung jawab sosial perusahaan dalam bentuk natura antara lain pemberian daging kurban saat Hari Raya Idul Adha, bibit tanaman yang dibagikan kepada petani, dan pembagian buku di sekolah dasar-sekolah dasar. Tanggung jawab sosial tersebut diberikan PT. IKPP Mills Tangerang secara rutin. Selain tanggung jawab sosial perusahaan yang dilakukan secara rutin, PT. IKPP Mills Tangerang juga pernah melakukan tanggung jawab sosial secara insidental. Tanggung jawab sosial perusahaan tersebut yaitu berupa proyek perbaikan sanitasi dan pemberian abate.

Adapun sektor yang biasanya diberikan sumbangan oleh PT. IKPP Mills Tangerang adalah sektor kesehatan, pendidikan, lingkungan, dan kegiatan keagamaan. Tanggung jawab sosial perusahaan dalam sektor kesehatan, yaitu kegiatan fogging dan donor. Tanggung jawab sosial perusahaan dalam sektor pendidikan, yaitu beasiswa, penghargaan anak karyawan, pembagian buku, dan lain-lain. Tanggung jawab sosial perusahaan dalam sektor lingkungan, yaitu penanaman pohon. Tanggung jawab sosial perusahaan dalam sektor kegiatan keagamaan diberikan saat hari besar keagamaan. Analisis needs assessment sebelum melakukan kegiatan tanggung jawab sosial perusahaan dilakukan PT. IKPP Mills Tangerang mulai tahun 2008 melalui social footprint. Kegiatan tanggung 
jawab sosial PT. IKPP Mills Tangerang tersebut tidak melibatkan masyarakat sekitar baik dalam proses perencanaan, pelaksanaan, maupun evaluasi kegiatan tanggung jawab sosial perusahaan.

Sasaran PT. IKPP Mills Tangerang untuk menerima tanggung jawab sosial perusahaan adalah masyarakat luas dan perusahaan (karyawan). PT. IKPP Mills Tangerang memilki yayasan khusus yang mengelola tanggung jawab sosial perusahaan. Yayasan tersebut adalah Eka Tjipta Foundation. Adapun motivasi PT. IKPP Mills Tangerang dalam melakukan tanggung jawab sosial tersebut adalah norma sosial dan hukum universal. Misi yang dibawa PT. IKPP Mills Tangerang dalam melakukan tanggung jawab sosial tersebut adalah memberikan kontribusi kepada masyarakat. Penyaluran tanggung jawab sosial perusahaan dilakukan PT. IKPP Mills Tangerang dengan cara membentuk panitia khusus dari PT. IKPP Mills Tangerang.

Beberapa kegiatan sosial perusahaan yang disebutkan oleh responden antara lain pemberian hewan kurban pada saat Hari Raya Idul Adha, bazar buku murah yang diadakan di sekolah di wilayah tersebut, santunan terhadap anak yatim piatu dan janda, penyemprotan nyamuk demam berdarah (fogging), sumbangan bahan-bahan bangunan untuk pembangunan mushollah, bantuan terhadap posyandu, dan penyuluhan terhadap petani yang mengelola lahan di belakang PT. IKPP Mills Tangerang. Selain itu, beberapa responden juga mengatakan bahwa perusahaan akan menurunkan bantuan kepada masyarakat sekitar apabila masyarakat sekitar mengajukan proposal untuk meminta bantuan kepada perusahaan.

Berdasarkan beberapa hal yang telah disebutkan di atas, maka dapat diketahui bahwa kegiatan tanggung jawab sosial perusahaan ini sebagian besar bersifat charity, seperti memberikan sumbangan kepada sekolah dasar yang berada di lingkungan sekitar, memberikan sumbangan setiap hari besar agama Islam, dan memberikan bantuan untuk janda dan yatim piatu. Tanggung jawab sosial perusahaan yang dilaksanakan oleh PT. IKPP Mills Tangerang dapat pula dikategorikan sebagai keinginan tulus perusahaan untuk melakukan kegiatan yang benar-benar berasal dari visi perusahaan itu. Hal ini tercermin dari program-program yang dijalankan untuk memenuhi kebutuhan masyarakat sekitar yang berbeda hasil dari perusahaan itu sendiri dan tidak berusaha untuk mengambil keuntungan materiil dari kegiatan tanggung jawab sosial yang dijalankannya tersebut.

\section{Pengaruh Upaya Perusahaan dalam Memperbaiki Persepsi Masyarakat Sekitar terhadap Persepsi Masyarakat Sekitar}

Upaya perusahan dalam memperbaiki persepsi masyarakat sekitar yang telah dilakukan oleh PT. IKPP Mills and Paper Tangerang meliputi komunikasi dan kegiatan tanggung jawab sosial perusahaan. Bagian ini membahas mengenai pengaruh komunikasi dan kegiatan tanggung jawab sosial perusahaan terhadap persepsi masyarakat sekitar.

\section{Pengaruh Upaya Komunikasi Perusahaan terhadap Persepsi Masyarakat Sekitar}

Upaya komunikasi PT. IKPP Mills Tangerang untuk membina hubungan baik dengan masyarakat sekitar dilakukan oleh bagian humas perusahaan. Adapun humas perusahaan mendapatkan tempat tersendiri di mata masyarakat sekitar. Salah seorang humas yang pernah tinggal di lingkungan masyarakat sekitar tersebut memiliki pengaruh yang besar dalam membentuk kesan baik perusahaan. Humas tersebut juga dapat menjalin hubungan baik secara personal kepada masyarakat sekitar sehingga sangat dikenal oleh sebagian besar masyarakat sekitar, meskipun pada saat penelitian berlangsung humas tersebut sudah tidak tinggal bersama masyarakat sekitar lagi. Tindakan perusahaan untuk mengirimkan humasnya saat melakukan pembuangan limbah ke sungai (pengontrolan limbah) merupakan hal yang cukup tepat. 
Masyarakat menganggap hal tersebut merupakan suatu tindakan yang menunjukkan perhatian perusahaan kepada masyarakat sekitar. Namun adanya pengontrolan tersebut sepertinya harus dijelaskan kepada masyarakat sekitar karena terdapat pandangan yang bertolak belakang dengan pandangan responden lainnya mengenai pelaksanaan pengontrolan tersebut. Responden tersebut menganggap tindakan tersebut merupakan bukti bahwa limbah yang dibuang oleh PT. IKPP Mills Tangerang sulit untuk diatasi.

\section{Pengaruh Kegiatan Tanggung Jawab Sosial Perusahaan terhadap Persepsi Masyarakat Sekitar}

Informasi mengenai kegiatan tanggung jawab sosial perusahaan yang dilakukan oleh PT. IKPP Mills Tangerang merupakan informasi yang paling banyak diketahui oleh responden. Melalui kegiatan tanggung jawab sosial perusahaan tersebut beberapa ekspektasi responden terhadap PT. IKPP Mills Tangerang dapat terpenuhi. Persepsi sebagian besar responden terhadap aktivitas PT. IKPP Mills Tangerang dapat diketahui positif pada hampir setiap aspek persepsi yang dikaji, kecuali pada aspek persepsi terhadap limbah yang dihasilkan oleh perusahaan.

Aspek persepsi yang berkaitan dengan pelaksanaan kegiatan tanggung jawab sosial perusahaan ini adalah persepsi terhadap dampak kehadiran PT. IKPP Mills Tangerang yang mencakup dampak sosial, ekonomi, dan lingkungan hidup. Ketiga aspek tersebut dinilai positif oleh sebagian besar responden. Kegiatan tanggung jawab sosial perusahaan mencakup sektor kesehatan, pendidikan, lingkungan, dan kegiatan keagamaan. Tanggung jawab sosial perusahaan PT. IKPP Mills Tangerang di keempat sektor tersebut dianggap responden bermanfaat bagi masyarakat sekitar.

\section{Kesimpulan}

Persepsi responden terhadap aktivitas PT. IKPP Mills Tangerang pada umumnya positif, kecuali pada aspek persepsi terhadap limbah yang dihasilkan oleh PT. IKPP Mills Tangerang. Faktor individu yang berhubungan dengan persepsi responden, yaitu tingkat kesejahteraan, status sosial, tingkat pendidikan, jenis pekerjaan, keterdedahan terhadap penerimaan pesan kegiatan sosial perusahaan, dan kebutuhan informasi tentang perusahaan. Strategi perusahaan dalam membina hubungan baik dengan masyarakat sekitar adalah dengan cara menjalin komunikasi dan melakukan tanggung jawab sosial perusahaan. Kegiatan komunikasi yang dilakukan oleh PT. IKPP Mills Tangerang termasuk dalam model asimetris dua arah, dimana PT. IKPP Mills Tangerang telah berusaha untuk menangkap umpan-balik dari masyarakat sekitarnya dengan cara menyebarkan kuesioner dan mendekati tokoh masyarakat untuk mengetahui isu-isu yang sedang berkembang. Kegiatan tanggung jawab sosial perusahaan sebagian besar bersifat charity dan termasuk dalam kategori keinginan tulus perusahaan untuk melakukan kegiatan yang benar-benar berasal dari visi perusahaan itu.

\section{Daftar Pustaka}

Ambadar J. 2008. CSR dalam Praktik di Indonesia. Jakarta (ID): PT. Elex Media Komputindo.

Hadi AP. 2001. Hubungan Antara Komunikasi Publik Perusahaan dan Sikap Komunitas Setempat (Kasus Perusahaan Pertambangan di Nusa Tenggara Barat) [tesis]. Program Pasca Sarjana. Institut Pertanian Bogor.

Herlin F. 2008. Analisis Tanggung Jawab Sosial Perusahaan (Corporate Social Responsibility/ CSR) sebagai Upaya Pengembangan Masyarakat (Studi Kasus Pengembangan Perekonomian Lokal Melalui Program Kemitraan PT. ANTAM Tbk di Tanjung Barat, 
Jakarta) [skripsi]. Program Studi Komunikasi dan Pengembangan Masyarakat. Institut Pertanian Bogor. Prasetyo, Bambang, Jannah LM. 2006. Metode Penelitian Kuantitatif: Teori dan Aplikasi. Jakarta: PT. Raja Grafindo Persada. 